\title{
Defensive Realism's Perspective on Rising China's Behavior as A Status Quo State
}

\author{
Vincentia Vahistha Hirrya Jyalita
}

Faculty of Social and Political Sciences, Universitas Katolik Parahyangan, Indonesia, jyalitav@gmail.com

\begin{abstract}
China's rise through rapid development especially in the economic sector have prompted debates on whether it seeks to overtake the United States (U.S.) and strive for domination. However, China insists that it has no such intentions since it benefits from the current system and wishes to pursue peaceful development. This paper will analyze why China is not seeking to displace the U.S. and alter the international order despite claims from offensive realism that states are revisionist as they pursue domination to guarantee its survival under anarchy. This paper argues that China prefers to be a status quo state because it receives security benefits under the circumstances of anarchy. The writer conducted the study with defensive realism's perspective and utilized indicators from Steve Chan, Weixing $\mathrm{Hu}$, and Kai He to determine whether China is a status quo state. The results show that China is indeed a status quo state that receives benefits for its security under anarchy. Moreover, this paper implies that defensive realism can be utilized as an alternative explanatory tool to offensive realism since not all states are revisionists after all.
\end{abstract}

Keywords: China; United States; Status Quo; Anarchy; Defensive Realism

\begin{abstract}
ABSTRAK
Kebangkitan China yang ditandai dengan perkembangan pesat, terutama dalam bidang ekonomi, telah memicu perdebatan tentang apakah China berusaha untuk mengambil alih kekuasaan Amerika Serikat (A.S.) dan mendominasi tatanan global. Namun, China bersikeras dalam mengklaim bahwa tidak ada niat seperti itu karena mendapatkan keuntungan dari sistem saat ini dan lebih ingin mengejar pembangunan secara damai. Artikel ini akan menganalisis mengapa China tidak berusaha untuk menggantikan A.S. maupun mengubah tatanan global, meskipun ada klaim dari offensive realism bahwa setiap negara adalah revisionist karena mereka memperluas kekuasaannya untuk menjamin kelangsungan hidupnya di bawah sistem dunia yang anarki. Dalam artikel ini, penulis berpendapat bahwa China lebih memilih menjadi negara status quo karena mendapatkan keuntungan di bidang keamanan di tengah situasi dunia yang anarki. Penulis melakukan studi dengan perspektif defensive realism dan menggunakan indikator dari Steve Chan, Weixing Hu, dan Kai He untuk menentukan apakah China merupakan negara status quo. Hasilnya menunjukkan bahwa China memang merupakan negara status quo yang mendapatkan keuntungan dalam bidang keamanan di tengah situasi dunia yang anarki. Selain itu, artikel ini menyiratkan bahwa defensive realism dapat digunakan sebagai teori alternatif selain offensive realism karena ternyata tidak semua negara tergolong sebagai revisionist.
\end{abstract}

Kata Kunci: China; Amerika Serikat; Status Quo; Anarki; Defensive Realism

\section{Introduction}

When looking at politics on a global level, the structure is different than that of politics on a domestic level. In comparison with domestic politics, the structure of global politics is that of anarchy. ${ }^{1}$ This means that states live in a world where no supreme authority exists above them and so

\footnotetext{
${ }^{1}$ Robert J. Art and Robert Jervis, International Politics: Enduring Concepts and Contemporary Issues $13^{\text {th }}$ Edition, (New York: Pearson, 2017), 3-51.
} 
there is no world government to make sure that all abide the law or anyone with the power to impose punishments on those who do not abide the law. ${ }^{2}$ As states do not recognize any superior power above them, they see themselves as their own highest authority. ${ }^{3}$

The anarchic structure of global politics has ramifications for the way states act and interact with each other. Under anarchy, there is a self-help system where states must rely on themselves to secure its own security. ${ }^{4}$ Since security is not assured in this anarchic world, offensive realists like Mearsheimer argue that all states act as revisionists since they must alter the system if they want to ensure their survival. ${ }^{5}$ Only after altering the system, will states be inclined to maintain the status quo. ${ }^{6}$

Following the argument of offensive realism, then a rising china will aim to displace the U.S. and alter the international order. At a first glance, this seems to be possible. In a span of around 40 years, China has dramatically transformed from being one of the world's poorest country with more than $88 \%$ of its citizens living under \$US 2 per day to becoming the world's second-biggest economy. ${ }^{7}$ China's success story has largely been accredited to economic reforms made in 1978 that opened China up to foreign investment and the outside world. ${ }^{8}$ Its rise has captured worldwide attention with most noting how its economy have climbed relative to other countries. ${ }^{9}$ When China surpassed Japan to become the world's second-biggest economy in 2010, it was regarded as an economic powerhouse after the United States (U.S.). ${ }^{10}$ Some economists even predict that its economy will eventually overtake that of the U.S. by $2030 .{ }^{11}$ On top of this, China has aimed to modernize its military capabilities which is reflected through its growth in military expenditure. ${ }^{12}$

However, upon closer inspection China's behavior seem to show the opposite of offensive realists' claim. Firstly, China's statements indicate a preference for maintaining the current system that is dominated by the U.S. This is reflected in various public statements since late 2003 where it emphasized that it strives for a peaceful rise. ${ }^{13}$ Most recently, it is also reflected through a White Paper in 2019 titled "China and the World in the New Era" where is stated that it is satisfied with the current international order. ${ }^{14}$ A revisionist state, on the other hand, would express in some way that it is dissatisfied and constrained by the current international order. ${ }^{15}$ Judging based on official statements alone, it appears so far that China has consistently put in the effort to present itself as a

\footnotetext{
${ }^{2}$ Art and Jervis, International Politics: Enduring Concepts and Contemporary Issues 13th Edition, 3.

${ }^{3}$ Baylis, Smith, and Owens, The Globalization of World Politics: An Introduction to International Relations $6^{\text {th }}$ Edition, 101.

${ }^{4}$ Art and Jervis, International Politics: Enduring Concepts and Contemporary Issues 13th Edition, 3.

${ }^{5}$ John J. Mearsheimer, The Tragedy of Great Power Politics (New York: W.W Norton \& Company, Inc, 2001), 1-55.

${ }^{6} \mathrm{Ibid}, 29-35$.

${ }^{7}$ Christina Zhou and Bang Xiao, "China's 40 years of economic reform that opened the country up and turned it into a superpower," $A B C$ News, December 2, 2018, https://www.abc.net.au/news/2018-12-01/40-years-of-reform-that-transformedchina-into-a-superpower/10573468.

${ }^{8}$ Ibid.

${ }^{9}$ Ibid.

${ }^{10}$ Yen Nee Lee, "Here are 4 charts that show China's rise as a global economic superpower," CNBC, September 23, 2019, https://www.cnbc.com/2019/09/24/how-much-chinas-economy-has-grown-over-the-last-70-years.html.

${ }^{11}$ Ibid.

${ }^{12}$ David Tweed, “China Defense Spending Set to Rise 7.5\% as Xi Builds Up Military,” Bloomberg, March 5, 2019, https://www.bloomberg.com/news/articles/2019-03-05/china-s-military-spending-slows-as-economy-cools.

${ }^{13}$ Zheng Bijian, China's Peaceful Rise: Speeches of Zheng Bijian 1997-2005, (New York: Brookings Institution Press, 2005), 13-17, https://www.jstor.org/stable/10.7864/j.ctt127xn6.

14 "China and the World in the New Era," The State Council of The People's Republic of China, accessed May 17, 2020, 2728, http://english.www.gov.cn/archive/whitepaper/201909/27/content WS5d8d80f9c6d0bcf8c4c142ef.html.

${ }^{15}$ Steve Chan, "Can't get no satisfaction? The recognition of revisionist states," Journal of International Relations of the Asia-Pacific 4, no. 2 (August 2004): 216, https://doi.org/10.1093/irap/4.2.207.
} 
peaceful status quo state. Secondly, China's actions seem to match with its statements of preferring to maintain the current system. One example of this would be China's preference towards bilateral negotiations that are aligned with international law to resolve disputes over land or sea with 12 neighboring countries. ${ }^{16}$ Another example is its significant role in promoting world security by becoming the second largest contributor towards the UN peacekeeping forces. ${ }^{17}$ This is unlike revisionist states who would disregard current international law and world security that have the purpose of preserving the current status quo. ${ }^{18}$

By discussing the matter of whether rising China is a status quo state, then policy makers can understand its behavior better and possibly avoid making policies that mistakenly frame China as a threatening revisionist. Therefore, this paper seeks to answer the question, why is rising China not seeking to displace the U.S. and alter the international order? The current hypothesis is that rising China prefers to be a status quo state because it receives benefits to its security in the circumstances of anarchy.

\section{Theory}

According to the defensive realist Kenneth Waltz, anarchy motivates states to achieve security which has several implications. ${ }^{19}$ The first implication is that attempts from a state to increase its own security can lead to a decrease in other states' security because of the threat it poses which is known as the security dilemma. ${ }^{20}$ In this case, creating mutual security through cooperation is preferred to reduce security dilemma. The second implication is that for these states, power is seen more as one of the potentially useful tool to obtain security instead of the final goal. ${ }^{21}$ Since maximizing power is not the final goal of states, states wish to preserve the current balance of power to ensure their security. This point leads to the third implication where from the perspective of these states, there is too many risks associated with attempting to dominate the system. ${ }^{22}$ For one, there is no assurance of success and they could acquire further loss instead. Another disincentive is that their effort will be deterred by other states who are defending their own security. The fourth implication is that states tend to act in defense than offense to avoid the high costs of war which causes them to restrain aggression. ${ }^{23}$ Hence, it can be understood that from the perspective of defensive realism, states tend to have the interest of defending the status quo. ${ }^{24}$ This argument disagrees with Mearsheimer's assertion from the offensive realism side. In Mearsheimer's view, anarchy drives states to maximize their power as the best way to ensure security. ${ }^{25}$ Since becoming the dominant power is the final goal then all states are revisionist

\footnotetext{
16 "China Remains Committed to Peaceful Settlement of Disputes in the South China Sea through Negotiations and Consultations," Ministry of Foreign Affairs of The People's Republic of China, accessed May 17, 2020, https://www.fmprc.gov.cn/mfa_eng/wjbxw/t1350776.shtml.

17 Joseph Nye, "China will not surpass America any time soon," Financial Times, February 19, 2019 https://www.ft.com/content/7f700ab4-306d-11e9-80d2-7b637a9e1ba1.

${ }^{18}$ Steve Chan, "Can't get no satisfaction? The recognition of revisionist states," Journal of International Relations of the AsiaPacific 4, no. 2 (August 2004): 216, https://doi.org/10.1093/irap/4.2.207.

${ }^{19}$ Kenneth N. Waltz, Theory of International Politics, (Philippines: Addison-Wesley, 1979), 126.

20 Robert Jervis, "Cooperation Under the Security Dilemma," World Politics 30, no. 2 (January 1978): 169, http://doi.org/10.2307/2009958.

${ }^{21}$ Waltz, Theory of International Politics, 126.

22 Jervis, "Cooperation Under the Security Dilemma," 193-195.

${ }^{23} \mathrm{Ibid}, 191-192$.

${ }^{24}$ Mearsheimer, The Tragedy of Great Power Politics, 20.; Randall L. Schweller, "Neorealism's status-quo bias: What security dilemma?” Journal of Security Studies 5, no. 3 (1996): 90-121, https://doi.org/10.1080/09636419608429277.

${ }^{25}$ Mearsheimer, The Tragedy of Great Power Politics, 34.
} 
and seek to change the balance of power which is why states tend to behave aggressively. ${ }^{26}$ Moreover, only the dominant state in the system can have interest to maintain the status quo. ${ }^{27}$

Based on the literatures above, states can be categorized into two types: revisionist and status quo states. Arnold Wolfers defines revisionist states as those who desire to change the values that are currently in place. ${ }^{28}$ Alternatively, status quo states are those who are content with the current values and wish to maintain it. ${ }^{29}$ Jason Davidson enriches Wolfers' study by adding that the values referred to here are valuable goods for the state which can include things such as ideology, markets, status, territory, international law and international institutions. ${ }^{30}$ Moreover, Randall Schweller asserts that revisionist states are willing to use military force to alter the values in their favor while status quo states would not resort to using military force. ${ }^{31}$ All in all, it can be summed up that revisionist states are states that wish to alter the current international order while status quo states are those that wish to keep it. ${ }^{32}$

Since defensive realism lacks analytical indicators to identify a status quo state, this paper will use Steve Chan, Weixing Hu, and Kai He's indicators to measures a state's commitment to the current international order and thus whether their behavior is status quo oriented. ${ }^{33}$ The first indicator is through official statements relating to international norms and the actions that are aligned with these statements. ${ }^{34}$ This indicator is important because it shows that the state chose to abide the internationally accepted norms. The international norms itself can be simply about accepting other states' territory and sovereignty as rightfully theirs and that force cannot be wrongfully used against other states. For this indicator, if the actions of the state matches with its words of support towards international norms then it can be regarded as a more solid proof that it tends to follow the rule of the game determined by the status quo. The second indicator is in its participation in international organizations, accords, and conventions. ${ }^{35}$ This indicator is also important since it shows that the state actively cooperates with other states for their common good. The common good underlies the creation of international organizations, accords, and conventions in the first place because simply, its goal is to solve a collective problem. On the other hand, a state's refusal to participate within international organizations and agreements implies that it is reluctant to accept the current international order. And the third indicator is in its voting history in the United Nations (UN) ${ }^{36}$ This indicator is needed because it illustrates that its interests are aligned with most states in the international community. When a state's voting history is frequently different from most countries, it implies that its interests clash with the international community's interests and would protest it.

\footnotetext{
${ }^{26}$ Ibid, 29-35.

${ }^{27}$ Ibid, 35 .

${ }^{28}$ Arnold Wolfers, Discord and Collaboration: Essays on International Politics (Baltimore: Johns Hopkins Press, 1962), 9092.

${ }^{29}$ Wolfers, Discord and Collaboration: Essays on International Politics, 90-92.

${ }^{30}$ Jason W. Davidson, The Origins of Revisionist and Status quo States (New York: Palgrave Macmillan, 2006), 13-14.

${ }^{31}$ Schweller, "Neorealism's status-quo bias: What security dilemma?" 98-100.

${ }^{32}$ Steve Chan, "Can't get no satisfaction? The recognition of revisionist states," Journal of International Relations of the Asia-Pacific 4, no. 2 (August 2004): 216, https://doi.org/10.1093/irap/4.2.207.

${ }^{33}$ Steve Chan, Weixing Hu, and Kai He, "Discerning states' revisionist and status quo orientations: Comparing China and the US," European Journal of International Relations 25, no. 2 (October 2018): 6-7, https://doi.org/10.1177/1354066118804622. ${ }^{34}$ Ibid, 6.

${ }^{35}$ Ibid, 6-7.

${ }^{36}$ Ibid, 7.
} 
The analysis will be divided into two parts. The first part will prove that rising China is a status quo state by looking at its official statements and actions relating to international norms, its participation in international organizations, accords, and conventions, and its voting history in the UN. Then, the second part will analyze why rising China's behavior is status quo oriented according to defensive realism.

\section{Analysis}

\section{Identifying rising China as a status quo state}

\section{a. Official Statements and Actions Relating to International Norms}

Using the first indicator that determines a status quo state by Steve Chan, Weixing $\mathrm{Hu}$, and $\mathrm{Kai} \mathrm{He}$, it can be considered that official statements from China matter in the way that statements of support or disagreement provide a glimpse into how it might view the current internationally accepted norms like sovereignty and limitations on the use of force. If China was a status quo state it would express support for these international norms, while if it was a revisionist state then would be keen on challenging these international norms. It was found that throughout recent years, China has consistently expressed in its official statements that it seeks to develop itself while still maintaining international peace and stability. Since late 2003, China has insisted through various public statements that it strives for a "peaceful rise" which will not disrupt the international order. Zheng Bijian, a former prominent senior government official in the Chinese Communist Party (CCP), first cemented the idea of China's peaceful development during a speech at the Bo'ao Forum for Asia that year. ${ }^{37}$

Then in 2005, China revealed its white paper with the name "China's Peaceful Development Road". The white paper contained China's commitment to pursue domestic development and still actively contribute to the greater good of the global community. ${ }^{38}$ In one part, China states that it seeks to respect sovereignty, promote world security, and strive for common development. ${ }^{39}$

Moreover, China reaffirmed its commitments to peaceful development in the 2019 White Paper titled "China and the World in the New Era". Within the White Paper, China states it has no intentions to strive for hegemony and challenge other states even when its strength is growing. ${ }^{40}$ It claims that doing so would only result in losses and that it is satisfied with the current international order from which it has largely benefited from. ${ }^{41}$

Based on the evidence of official statements alone for the first indicator of a status quo state, it is clear that China has continuously expressed its desire to develop itself while still following international norms such as sovereignty and limitations on the use of force. China's consistent expression of support for these norms can be interpreted as a reflection of their firm belief towards the international norms of sovereignty and limitations on the use of force.

\footnotetext{
${ }^{37}$ Bijian, China's Peaceful Rise: Speeches of Zheng Bijian 1997-2005, 13-17.

38 "White Paper on China's Peaceful Development Road," China Report 42, no. 2 (2006): 215-232, https://doi.org/10.1177/000944550604200208.

${ }^{39}$ China Report, "White Paper on China's Peaceful Development Road," 227-229.

${ }^{40}$ The State Council of The People's Republic of China, "China and the World in the New Era," 27-28.

${ }^{41}$ Ibid.
} 
Using the theory of defensive realism, it can be analyzed that the evidence from China's official statements that indicate support for international norms also shows that is a status quo state since they tend to wish avoiding attracting unwanted caution from other countries under the circumstances of anarchy where their security is not guaranteed. If China were to explicitly express that it detests the internationally accepted norms of sovereignty and limitations on the use of force, then it would be seen as a possible threat that warrants suspicion from other states. So, expressing itself as a status quo state that respects international norms are safer for China's security. However, for their words to hold more weight, its actions need to be analyzed as well.

As a part of the first indicator outlined by Steve Chan, Weixing Hu, and $\mathrm{Kai} \mathrm{He}$, China's actions also matter since it determines whether it statements of support for the internationally accepted norms are actually implemented. A true status quo state would act in support for these international norms while a revisionist state would actively challenge these international norms. Based on its actions, China's actions have thus far reflected their claims of international norms of sovereignty and limitations on the use of force. In terms of respect to sovereignty, China has prioritized bilateral negotiations that follows international laws as mechanism to settle territorial disputes. For instance, China resolved land or sea disputes with 12 neighboring countries including Vietnam through negotiations. ${ }^{42}$ By preferring to settle territorial disputes through bilateral negotiations that follows the international laws instead of forcefully imposing its territorial claims, it means that China respects the international norm of sovereignty and limitations on the use of force. Here it is evident that China's actions are aligned with its claims of wanting to pursue peaceful development without breaking the international norms of sovereignty and limitations on the use of force.

Through the perspective of defensive realism, it can be analyzed that the evidence from China's actions of support towards international norms also indicates that it is a status quo state because they tend to avoid violating other states' sovereignty and using force. This is because under anarchy, attempts from China to dominate other states, that would clearly violate sovereignty and the limitations on the use of force, would be countered through military means by other states who also wish to defend their security. The defensive military response from other states is one of the disincentives of attempts to dominate other states that anarchy creates. Another disincentive that anarchy creates is the lack of assurance of success for China and as a result they could even experience further loss consisting of damage to its own military resources and security. Meanwhile, implementing support for international norms of sovereignty and limitations on the use of force in its actions give China a friendly image among other countries and lowers tensions that would otherwise be caused if China disregarded the aforementioned international norms.

\section{b. Participation in International Organizations, Accords, and Conventions}

In the second indicator by Steve Chan, Weixing Hu, and Kai He, membership or lack of in international organizations tells China's willingness to participate and cooperate alongside other states under the current international order. A status quo state would be keen on being

${ }^{42}$ Ministry of Foreign Affairs of The People's Republic of China, "China Remains Committed to Peaceful Settlement of Disputes in the South China Sea through Negotiations and Consultations." 
involved in international organizations and contribute to the common good while a revisionist state would be reluctant to join international organizations. Early in its history China was not an active member of international organizations. Only after it started opening itself to the world in the 1970s did it begin to assume active membership in several intergovernmental organizations (IGOs). ${ }^{43}$ In 1971, China finally became a member of the United Nations. ${ }^{44}$ Not long after, it became increasingly involved in other IGOs such as the International Monetary Fund and World Bank. ${ }^{45}$ To put into perspective the extent of its activeness over the years, in 1966 China was a member of only one IGO while in 2000 its membership exceeded 50 IGOs. ${ }^{46}$ Based on China's growing membership in international organizations, it is apparent that China has shown increasing commitment to cooperate with other states alongside its rapid development under the current international order that is led by the U.S. It can be interpreted that China is keen on being a fellow cooperative state for the common good.

From the view of defensive realism, this evidence of China's growing membership in international organizations also shows that it is a status quo state since status quo states wish to preserve its security under the circumstances of anarchy in a way that will not be met with hostility by other states. The reason for this is because under anarchy, China will face a security dilemma if it attempts to increase its own security where it is challenged by other states who feel threatened. China's participation in international organizations can therefore reduce this security dilemma by creating opportunities to cooperate with other states in creating mutual security.

Then as a continuation of the second indicator by Steve Chan, Weixing $\mathrm{Hu}$, and $\mathrm{Kai} \mathrm{He}$, international accords and conventions shows China's stance in various global issues. If China was a status quo state then it would be keen on joining agreements alongside other states on various global issues which means they are willingly a part of the international community for the sake of the common good, while if China was a revisionist state then it would be on the opposite side. It was found that in international accords and conventions, China has signed and ratified the following agreements but not limited to; Treaty on the Non-Proliferation of Nuclear Weapons, Convention on Nuclear Safety, Convention against Torture and Other Cruel Inhuman or Degrading Treatment or Punishment, International Covenant on Economic, Social and Cultural Rights, and Paris Agreement. ${ }^{47}$ The ratification of these agreements indicate that China also acknowledges the importance of these topics alongside other countries and is willing to be a part of the international community for the sake of the common good.

\footnotetext{
${ }^{43}$ Samuel S. Kim, "International Organizations in Chinese Foreign Policy," The ANNALS of the American Academy of Political and Social Science 519, no. 1 (1992): 143, https://doi.org/10.1177/0002716292519001011.

${ }^{44} \mathrm{Ibid}, 141$.

${ }^{45}$ Ann Kent, "China's Participation in International Organisations," in Power and Responsibility in Chinese Foreign Policy, eds, Zhang Yongjin and Austin Greg (Canberra: ANU Press, 2013), 132-133, https://www.jstor.org/stable/j.ctt5vj73b.11.

${ }^{46} \mathrm{Ibid}, 133$.

47 "List of Arms Control, Disarmament and Non-Proliferation Treaties that China has Joined," Ministry of Foreign Affairs of The People's Republic of China, accessed May 17, https://www.fmprc.gov.cn/mfa_eng/wjb_663304/zzjg_663340/jks_665232/tyylb_665254/t141338.shtml.; "UN Treaty Body Database: China," United Nations Human Rights Office of The High Commissioner, accessed May 17, 2020, https://tbinternet.ohchr.org/_layouts/15/TreatyBodyExternal/Treaty.aspx?CountryID=36\&Lang=EN.;"Paris Agreement," United Nations Treaty Collection, accessed May 2020 , https://reaties.un.org/Pages/ViewDetails.aspx?src=TREATY\&mtdsg_no=XXVII-7-d\&chapter=27\&clang=_en.
} 
Utilizing the view of defensive realism, this evidence of China's participation in various global agreements shows that it is behaving like a status quo state by presenting itself as agreeable across several topics which can be a useful tool for status quo states to obtain security. It can be concluded that in defensive realism, the end goal of the state after all is to achieve security because this is what anarchy pushes them to do. This method of joining global agreements is useful because it adds positivity to China's image as a fellow cooperative state that is willing to contribute to the common good and does not raise tensions from other states.

\section{c. Voting History in the UN}

In the third indicator by Steve Chan, Weixing $\mathrm{Hu}$, and $\mathrm{Kai} \mathrm{He}$, China's voting history in the UN matter because it shows whether China's preferences are aligned with other states in the UN that represents the international community. If China was a status quo state then its voting history in the UN would tend to agree with the majority of the international community, while if it was a revisionist state then China would tend to disagree. The following data lists China's voting history in the UN General Assembly (UNGA) 1971-2018 across six topics: IsraelPalestinian conflict (ME), Nuclear Weapons (NU), Arms Control (DI), Human Rights (HR), Colonialism (CO), and Economic Development (EC).

Table 1. China's Voting History in the UNGA, 1971-2018

\begin{tabular}{cccccccc}
\hline Voting & Me & NU & DI & HR & CO & EC & Total \\
\hline Yes & 949 & 504 & 685 & 698 & 622 & 492 & 3950 \\
No & - & 44 & 39 & 93 & - & - & 176 \\
Abstain & - & 147 & 159 & 76 & - & 55 & 437 \\
\multicolumn{2}{l}{ Source: Erik Voeten, 2013 (modified from Aljazeera) } \\
(8)
\end{tabular}

Based on the data above, it is apparent that a majority of China's voting history in the UNGA consists of agreements with the resolutions proposed across six topics. The total for agreements is 3950 from 1971-2018. ${ }^{49}$ In comparison, disagreements consist the least of China's voting history with a total of 176 times from 1971 until 2018 while the choice to abstain from voting amounts to 437 times. ${ }^{50}$ From this data it is apparent that China tends to frequently agree with the majority of the international community on all the topics discussed at the UNGA. In the UN Security Council (UNSC), China is a permanent member with the right to veto resolutions. The following data lists China's veto history compared to other permanent members in the UNSC.

\footnotetext{
48 “How has my country voted at the UN?" Aljazeera, accessed May 17, 2020, https://interactive.aljazeera.com/aje/2019/howhas-my-country-voted-at-unga/index.html.; Erik Voeten "Data and Analyses of Voting in the UN General Assembly" in Routledge Handbook of International Organization, ed. Bob Reinalda (London: Routledge, 2013).

${ }^{49}$ Ibid.

${ }^{50}$ Aljazeera, "How has my country voted at the UN?"; Voeten, "Data and Analyses of Voting in the UN General Assembly."
} 
Table 2. UNSC's Veto History, 1971-2019

\begin{tabular}{ccc}
\hline Country & Vetoes in Numbers & Vetoes (\%) \\
\hline United States & 80 & 65.5 \\
Russia/USSR & 38 & 38.1 \\
United Kingdom & 24 & 19.7 \\
France & 14 & 11.5 \\
China & 14 & 11.5 \\
Total & 122 & 100.0 \\
\hline
\end{tabular}

Source: United Nations, 2019 (modified from Center for Strategic and International

Studies $)^{51}$

According to the data, China has used its veto right the least along with France. China's use of veto totals to $14 .{ }^{52}$ In percentages, China's frequency to veto would be at $11.5 \%$ from the years 1971 until 2019. ${ }^{53}$ In comparison, the U.S. has used its veto right the most out of the other countries in the list with a total of 80 vetoes with a frequency of $65.5 \%$ in the same period. ${ }^{54}$

Based on the data above, it is apparent that China usage of veto is a part of the lowest out of the other states which shows that it mostly agrees with the rest of the international community on resolutions proposed in the UNSC.

From the perspective of defensive realism, it can be analyzed that China would face disincentives from attempting to challenge and dominate the system such as deterrence by other states. This evidence of China's tendency to agree alongside most of the international community in terms of its voting history in the UN shows it is a status quo state because China can be interpreted as reluctant to challenge the current international order because it is aware of the disincentives. These disincentives exist in the first place because according to defensive realism in the circumstances of anarchy, the security of states is not guaranteed by a world government.

\section{Reasons Behind Rising China's Preference to be a Status Quo State}

In the previous section, it has been proven that rising China can be categorized as a status quo state. This would partly explain why rising China is not seeking to displace the U.S. and alter the international order. To get a more complete picture, the reasons why rising China has preferred to be a status quo state instead of a revisionist state will be explained in this section from the perspective of defensive realism.

It can be argued using the theory of defensive realism that rising China prefers to be a status quo state because it has benefits for their security in the circumstances of anarchy. The first benefit that China earns by being a status quo state in the world condition of anarchy is that they will not face any significant challenge from other states because they are not viewed as an

\footnotetext{
51 "Is China contributing to the United Nations' mission?" CSIS, accessed May 17, 2020, https://chinapower.csis.org/chinaun-mission/.; "Security Council - Veto List" CSIS, accessed May 17, 2020, https://research.un.org/en/docs/sc/quick.

${ }^{52}$ Ibid.

${ }^{53}$ CSIS, "Is China contributing to the United Nations' mission?"; CSIS, "Security Council - Veto List."

${ }^{54}$ Ibid.
} 
aggressor. The evidence of this can be seen from the partnerships that is has been able to conduct with other countries in various sectors like the economy. For example, China was able to create partnerships with 78 countries and 5 regional organizations like the European Union and ASEAN as 2016 came to a close. ${ }^{55}$ These partnerships include partnerships for common development, friendship and cooperation, strategic mutual benefits and more. ${ }^{56}$ Hence, it is apparent that China benefits by being a status quo state in the circumstances of anarchy since they can avoid being treated with hostility by other states and can even form partnerships with the other states.

The second benefit for China as a status quo state in this anarchic world is that it can ensure its economic security without resorting to aggressive means that undermines their economic security. Economic security can be undermined when aggressive means are used because there are high costs involved in the activity of waging war against other states. The high costs can involve funding for the usage of resources such as military troops, transportation, fuel and ammunition. There are also additional costs that may come after the war ends and require a long time to recover such as the loss of resources, lives, and property. Take for example, the estimated costs that burdens the U.S. for carrying out wars against Afghanistan and Iraq are around \$US 4 trillion to \$US 6 trillion, excluding the economic costs in the long run. ${ }^{57}$ The effort of waging war for China does not necessarily bring guarantee either that it will be successful due to the condition of anarchy that pushes other states to respond to security threats. Looking at the case study, it is apparent that accordingly, China has ensured its economic security under the current international order led by the U.S. without the necessity of using aggressive means. Within 40 years, China has grown economically to become the world's second-biggest economy despite being one of the world's poorest country before with more than $88 \%$ of its citizens living below \$US 2 each day. ${ }^{58}$ This was largely possible due to the economic reforms that opened China to the outside world and foreign investment in $1978 .{ }^{59}$ Moreover, in 2010 China eventually surpassed Japan to become the world's second-biggest economy which earned it the title of an economic powerhouse after the U.S. ${ }^{60}$ It has been predicted by some economists that China's economy will eventually overtake the U.S. by $2030 .{ }^{61}$ All of this has occurred alongside China's increasing involvement in the international community through joining international organizations, agreements, and partnerships that have been mentioned before. So here it is clear that China's economic security has benefited under the current international order that is dominated by the U.S. without having to conduct any wars with the U.S. for power over this international order.

The third benefit that China receives by being a status quo state is increasing its security without being viewed with suspicion through the establishment of mutual security with the international community. As mentioned before using defensive realism, under anarchy there is a

\footnotetext{
${ }^{55}$ Quan Li and Min Ye, “China's emerging partnership network: what, who, where, when and why," International Trade, Politics, and Development 3, no. 2 (2019): 66, https://doi.org/10.1108/ITPD-05-2019-0004.

${ }^{56}$ Ibid, 68.

${ }^{57}$ Joseph E. Stiglitz and Linda J. Bilmes, "Estimating the Costs of War: Methodological Issues, with Applications to Iraq and Afghanistan," The Oxford Handbook of the Economics of Peace and Conflict (2012): 35, https://doi.org/10.1093/oxfordhb/9780195392777.013.0013/.

${ }_{58}$ Zhou and Xiao, "China's 40 years of economic reform that opened the country up and turned it into a superpower."

${ }^{59} \mathrm{Ibid}$.

${ }^{60}$ Lee, "Here are 4 charts that show China's rise as a global economic superpower."

${ }^{61}$ Ibid.
} 
security dilemma where attempts by a state to increase its security causes other states to respond against them. To mitigate this, China has contributed in efforts to enhance world security by contributing to the UN's peacekeeping forces. In fact, China comes second in the list of countries who contribute most towards UN peacekeeping forces. ${ }^{62}$ By showing that it contributes to world security, then other states are less likely to treat China with hostility and more willing to cooperate with them through security partnerships. For example, in the Southeast Asia region, China has formed security partnerships with countries like Laos and Malaysia in the form of defense dialogues and military exercises. ${ }^{63}$ This means that China has been able to increase its security under the framing of mutual security with other countries to avoid the suspicion that it would have received from other states if it had suddenly increased its security on its own.

\section{Conclusion}

This paper has the objective of analyzing why China as a rising power, is reluctant to challenge the U.S. and alter the international order. The answer to the aforementioned research question is that China is reluctant to challenge the U.S. and alter the international order because it is a status quo state who receives security benefits in the circumstances of anarchy. This is reflected in the analysis where it was found that China's behavior is more aligned with status quo states and it receives benefits to its security by being a status quo state such as not facing security challenges by other states, being able to ensure its economic security without aggressive and costly methods, and increasing its security in a way that does not warrant suspicion that is through collaboration with other states. Another significant finding in this paper is that not all states are revisionists which indicates that there is a gap in offensive realism when explaining state behavior under anarchy. To fill that gap, this paper suggests that defensive realism can be utilized as an alternative explanatory tool.

\footnotetext{
${ }^{62}$ Nye, "China will not surpass America any time soon."

${ }^{63}$ Prashanth Parameswaran, Managing the Rise of China's Security Partnerships in Southeast Asia (Washington, D.C.: Wilson Center Asia Program, https://www.wilsoncenter.org/sites/default/files/media/documents/publication/201807_managing_the_rise_of_chinas_security_partnerships_in_southeast_asia_-_parameswaran.pdf.
} 


\section{References}

Books:

Art, Robert J., and Robert Jervis. International Politics: Enduring Concepts and Contemporary Issues 13th Edition. New York: Pearson, 2017.

Baylis, John., Steve Smith, and Patricia Owens. The Globalization of World Politics: An Introduction to International Relations 6th Edition. United Kingdom: Oxford University Press, 2014.

Bijian, Zheng. China's Peaceful Rise: Speeches of Zheng Bijian 1997-2005. New York: Brookings Institution Press, 2005. https://www.jstor.org/stable/10.7864/j.ctt127xn6.

Davidson, Jason W. The Origins of Revisionist and Status quo States. New York: Palgrave Macmillan, 2006.

Kent, Ann. "China's Participation in International Organisations." In Power and Responsibility in Chinese Foreign Policy, edited by Zhang Yongjin and Austin Greg, 132-133. Canberra: ANU Press, 2013. https://www.jstor.org/stable/j.ctt5vj73b.11.

Mearsheimer, John J. The Tragedy of Great Power Politics. New York: W.W Norton \& Company, Inc, 2001.

Voeten, Erik. "Data and Analyses of Voting in the UN General Assembly." In Routledge Handbook of International Organization, edited by Bob Reinalda. London: Routledge, 2013.

Waltz, Kenneth N. Theory of International Politics. Philippines: Addison-Wesley, 1979.

Wolfers, Arnold. Discord and Collaboration: Essays on International Politics. Baltimore: Johns Hopkins Press, 1962.

Journals:

Chan, Steve. "Can't get no satisfaction? The recognition of revisionist states." Journal of International Relations of the Asia-Pacific 4, no. 2 (August 2004): 216. https://doi.org/10.1093/irap/4.2.207. 
Chan, Steve., Weixing Hu, and Kai He. "Discerning states' revisionist and status quo orientations: Comparing China and the US." European Journal of International Relations 25, no. 2 (October 2018): 6-7. https://doi.org/10.1177/1354066118804622.

China. "White Paper on China's Peaceful Development Road." China Report 42, no. 2 (2006): 215232. https://doi.org/10.1177/000944550604200208.

Jervis, Robert. "Cooperation Under the Security Dilemma." World Politics 30, no. 2 (January 1978): 167-214, http://doi.org/10.2307/2009958.

Johnston, Alastair Lain. "Is China a Status quo Power?" Journal of International Security 27, no. 4 (Spring 2003): 5-56. https://www.jstor.org/stable/4137603.

Kim, Samuel S. "International Organizations in Chinese Foreign Policy.” The ANNALS of the American Academy of Political and Social Science 519, no. 1 (1992): 143. https://doi.org/10.1177/0002716292519001011.

Li, Quan, and Min Ye. "China's emerging partnership network: what, who, where, when and why." International Trade, Politics, and Development 3, no. 2 (2019): 66-81, https://doi.org/10.1108/ITPD-05-2019-0004.

Qin, Yaqing. "Development of International Relations theory in China: progress through debates." International Relations of the Asia-Pacific 11, no. 2 (May 2011): 231-257. https://doi.org/10.1093/irap/lcr003.

Schweller, Randall L. "Neorealism's status-quo bias: What security dilemma?" Journal of Security Studies 5, no. 3 (1996): 90-121. https://doi.org/10.1080/09636419608429277.

Stiglitz, Joseph E., and Linda J. Bilmes. "Estimating the Costs of War: Methodological Issues, with Applications to Iraq and Afghanistan." The Oxford Handbook of the Economics of Peace and Conflict (2012): 35, https://doi.org/10.1093/oxfordhb/9780195392777.013.0013.

Wendt, Alexander. "Anarchy is What States Make of it: The Social Construction of Power Politics." $\begin{array}{lllll}\text { International Organization } 46, & \text { no. } & 2 & \text { (1992): }\end{array}$ https//doi.org/10.1017/S0020818300027764.

Reports:

Parameswaran, Prashanth. Managing the Rise of China's Security Partnerships in Southeast Asia.

Washington, D.C.: Wilson Center Asia Program, 2019. https://www.wilsoncenter.org/sites/default/files/media/documents/publication/201807_managing_the_rise_of_chinas_security_partnerships_in_southeast_asia_-_parameswaran.pdf.

News Articles:

Aljazeera. "How has my country voted at the UN?" Accessed May 17, 2020. https://interactive.aljazeera.com/aje/2019/how-has-my-country-voted-at-unga/index.html.

Goldring, Kira. "Here's why China could overtake the US as the next superpower - and why it might not." Business Insider. June 2, 2018. https://www.businessinsider.com/the-argument-for-andagainst-china-overtaking-the-us-as-superpower-2018-6? IR=T.

Lee, Yen Nee. "Here are 4 charts that show China's rise as a global economic superpower." $C N B C$. September 23, 2019. https://www.cnbc.com/2019/09/24/how-much-chinas-economy-has-grownover-the-last-70-years.html. 
Nye, Joseph. "China will not surpass America any time soon." Financial Times. February 19, 2019. https://www.ft.com/content/7f700ab4-306d-11e9-80d2-7b637a9e1ba1.

Tweed, David. "China Defense Spending Set to Rise 7.5\% as Xi Builds Up Military." Bloomberg. March 5, 2019. https://www.bloomberg.com/news/articles/2019-03-05/china-s-military-spendingslows-as-economy-cools.

Xia, Ming. "'China Threat' or a 'Peaceful Rise of China'?" The New York Times. https://archive.nytimes.com/www.nytimes.com/ref/college/coll-china-politics-007.html.

Zhou, Christina., and Bang Xiao. "China's 40 years of economic reform that opened the country up and turned it into a superpower." $A B C$ News. December 2, 2018. https://www.abc.net.au/news/2018-12-01/40-years-of-reform-that-transformed-china-into-asuperpower/10573468.

Websites:

CSIS "Security Council - Veto List." Accessed May 17, 2020. https://research.un.org/en/docs/sc/quick.

CSIS. "Is China contributing to the United Nations' mission?" Accessed May 17, 2020. https://chinapower.csis.org/china-un-mission/.

Longworth, Richard C. "US-China: A Shared Vision of Global Economic Partnership." Accessed March 6, 2020. https://www.thechicagocouncil.org/event/us-china-shared-vision-global-economicpartnership.

Ministry of Foreign Affairs of The People's Republic of China. "China Remains Committed to Peaceful Settlement of Disputes in the South China Sea through Negotiations and Consultations," Accessed May 17, 2020. https://www.fmprc.gov.cn/mfa_eng/wjbxw/t1350776.shtml.

Ministry of Foreign Affairs of The People's Republic of China. "List of Arms Control, Disarmament and Non-Proliferation Treaties that China has Joined." Accessed May 17, 2020.

https://www.fmprc.gov.cn/mfa_eng/wjb_663304/zzjg_663340/jks_665232/tyylb_665254/t141338. shtml.

The State Council of The People's Republic of China. "China and the World in the New Era,"
Accessed
May
17 ,
2020 ,
$1-49$. http://english.www.gov.cn/archive/whitepaper/201909/27/content_WS5d8d80f9c6d0bcf8c4c142ef .html.

United Nations Human Rights Office of The High Commissioner. "UN Treaty Body Database:

China.” Accessed May 17, 2020. https://tbinternet.ohchr.org/_layouts/15/TreatyBodyExternal/Treaty.aspx?CountryID=36\&Lang=E $\mathrm{N}$.

United Nations Treaty Collection. "Paris Agreement." Accessed May 17, 2020. https://treaties.un.org/Pages/ViewDetails.aspx?src=TREATY\&mtdsg_no=XXVII-7$\mathrm{d} \&$ chapter $=27 \&$ clang $=$ en . 